\title{
Free Roast Pig at Open Day: All you can eat will not attract South Auckland Pacific Islanders to University
}

\begin{abstract}
I kid you not. This is a time in Pacific regional history where as a middle-aged Tongan woman with European, Maori, and Samoan ancestries who was born and raised in New Zealand, I teach students taking my undergraduate papers how not to go about making stereotypical assumptions. The students in my classes are mostly Maori and Pakeha (white, European) New Zealanders. They learn to interrogate typecasts produced by state policy, media, and academia classifying the suburbs of South Auckland as overcrowded with brown people, meaning Pacific Islanders; overburdened by non-communicable diseases, like obesity and diabetes; and overdone in dismal youth statistics for crime and high school drop-outs. And then some well-meaning but incredibly uninformed staff members at the university where I am a senior lecturer have a bright idea to give away portions of roast pig on a spit to Pacific Islanders at the South Auckland campus open day.

Who asked the university to give us free roast pig? Who asked us if this is what we want from a university that was planted out South in 2010 to sell degrees to a South Auckland
\end{abstract}


market predicted to grow to half a million people, largely young people, in the next two decades? (AUT University, 2014). Who makes decisions about what gets dished up to Pacific Islanders in South Auckland, compared to what their hopes might be for university education prospects? To rephrase Julie Landsman's essay, how about "confronting the racism of low expectations" that frames and bounds Pacific Islanders in South Auckland when a New Zealand university of predominantly Palangi (white, European) lecturers and researchers on academic staff contemplate "closing achievement gaps?" (Landsman, 2004).

Tackling "the soft bigotry of low expectations" set upon Pacific Islanders getting into and through the university system has prompted discussion around introducing two sets of ideas at Auckland University of Technology (The Patriot Post, 2014). First, a summer school foundation course for literacy and numeracy on the South campus, recruiting Pacific Islander school leavers wanting to go on to study Bachelor's degrees. Previously, the University of Auckland had provided bridging paths designed for young Pacific peoples to step up to degree programmes (Anae et al, 2002).

Second, the possibility of performing arts undergraduate papers recognising a diverse and youthful ethnoscape party to an Auckland context of theatre, drama, dance, music, Maori and Pacific cultural performance, storytelling, and slam poetry (Appadurai, 1996). Although this discussion is in its infancy and has not been feasibility scoped or formally initiated in the university system, it is a suggestion worth considering here.

My inquiry is frank: Why conflate performance and South Auckland Pacific Islanders? Does this not lend to a clichéd mould that supposes young Pacific Islanders growing up in the ill-famed suburbs of the poor South are naturally gifted at singing, dancing, and performing theatrics? This is a characterisation fitted to inner-city Black American youth that 
has gone global and is wielded to tag, label, and brand urban Pacific Islanders of South Auckland. Therefore, how are the aspirational interests of this niche market reflected in the content and context of initiatives with South Auckland Pacific Islander communities in mind?

\section{My son Rewi deserves more than free roast pig}

I am Tongan by paternity and I live in Otahuhu, a South Auckland suburb known for its large Tongan population dwelling alongside other Pacific Island ethnicities and South East Asian minorities from India, Pakistan, and Sri Lanka. I am a single parent and the sole income earner and provider for my children living at home. I do not eat pig impaled on a steel skew and sizzled by an electric rotisserie cooker. Even as a child I did not partake in what is generalised as a Tongan titbit. My father migrated to New Zealand in 1966 from the Kingdom of Tonga and to this day has held on to his Tongan citizenship for forty eight years. My parents live in Manurewa, another suburb of the South, and can attest to their only child having an aversion to a carcass of pig skewed, sizzled, and spit roasted.

Why would employees at a New Zealand university presume Pacific Islanders automatically want to devour a whole cooked pig at an open day set up to recruit students to enrol in degree programmes? What is more, when it is allied (not academic) staff at the university who identify as Pacific Islanders making the call that free roast pig is the ideal recruitment strategy to draw in young people from the communities, one has to ask, what were they thinking? The insinuation is this social group requires enticing with a free porker, and they would likely attend the university's open day if all you can eat fatty meat was up for grabs. 


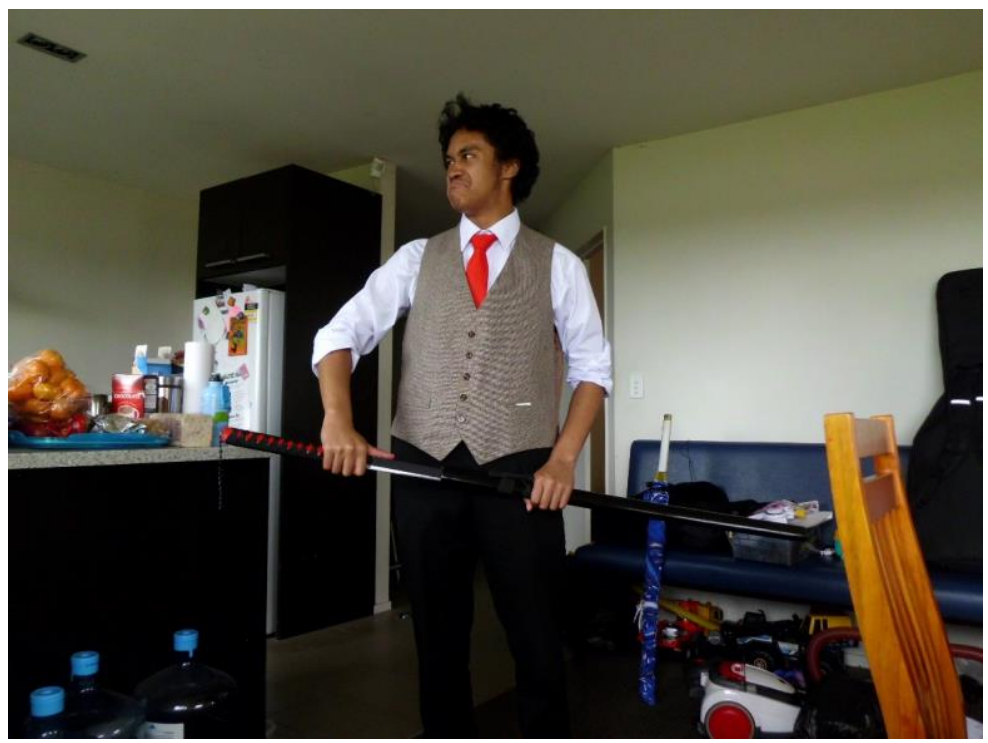

The author's son, Rewi Maniapoto Amoamo, aged 16 years old. In characterisation here, he attended Armageddon, an entertainment expo held in Auckland dressed in costume with a plastic Samurai sword and a pink wig.

I am speaking of Pacific Islanders who are geographically defined and confined by living in South Auckland. Located in a specific part of Auckland, this is an area that gets separated out and taken apart by others not from this place who want to gawk at the South judging what it is, what it likes to consume, and what needs to be done to it. The South, the label that Auckland University of Technology has given to its campus in Manukau City, is uncritically imagined into existence as an object and a thing that can be allured, signed up, and controlled in a state education system not historically designed with it in mind.

This is my foremost objection, not singly as a critic and an anthropologist of the Pacific Islands region, but as a South 
Auckland resident and the mother of children growing up and attending school here who distinguish themselves from others as coming from this place. In writing, I am positioned awkwardly as an insider and an outsider. However, this is not an unusual predicament for me to be located and dislocated in between peoples and places. By this, I have experience in advocating criticism of the Tongan state and Pacific regional organisations from communities on the ground affected by high-level decisions made about them, without their involvement. I am also accustomed to being side-lined, silenced, and spoken poorly about (behind my back) for my time and trouble in speaking back to the establishment (Brown Pulu, 2011). 


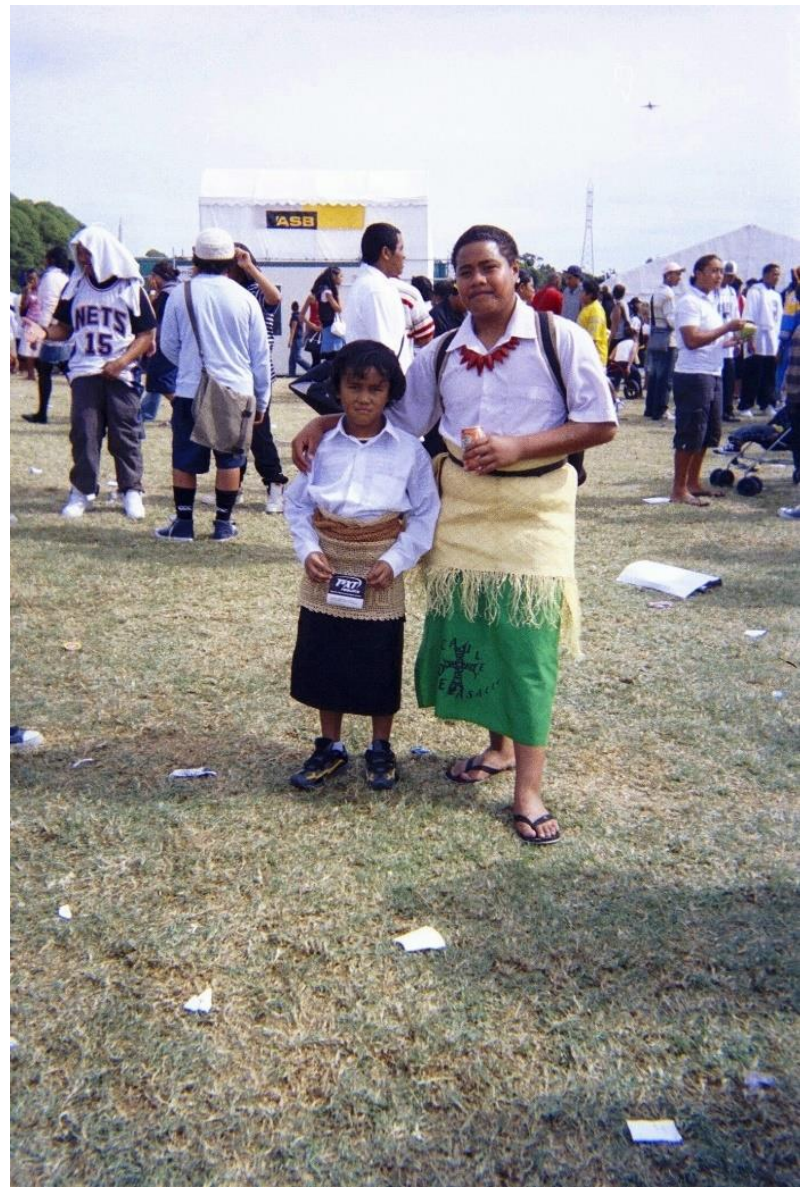

The author's son, Rewi Maniapoto Amoamo (left), aged 6 years old. Dressed in a Tongan ta'ovala and standing with his older cousin Tofa Talau at the Auckland secondary schools Polynesian festival held annually in Otara, South Auckland.

To explain the circumstantial ground spurring me to put pen to paper, my sixteen year old son Rewi Maniapoto Amoamo is a year 11 student at Otahuhu College, the local 
high school which is within walking distance from our home. Rewi is in zone, which means because he lives in Otahuhu the college is obligated to prioritise his enrolment. In zone proved a useful policy when Rewi decided in term three of 2014 he wanted to move back to a mainstream public high school, rather than complete secondary education at a total immersion school where the language of instruction was $\mathrm{Te}$ Reo Maori (Maori language).

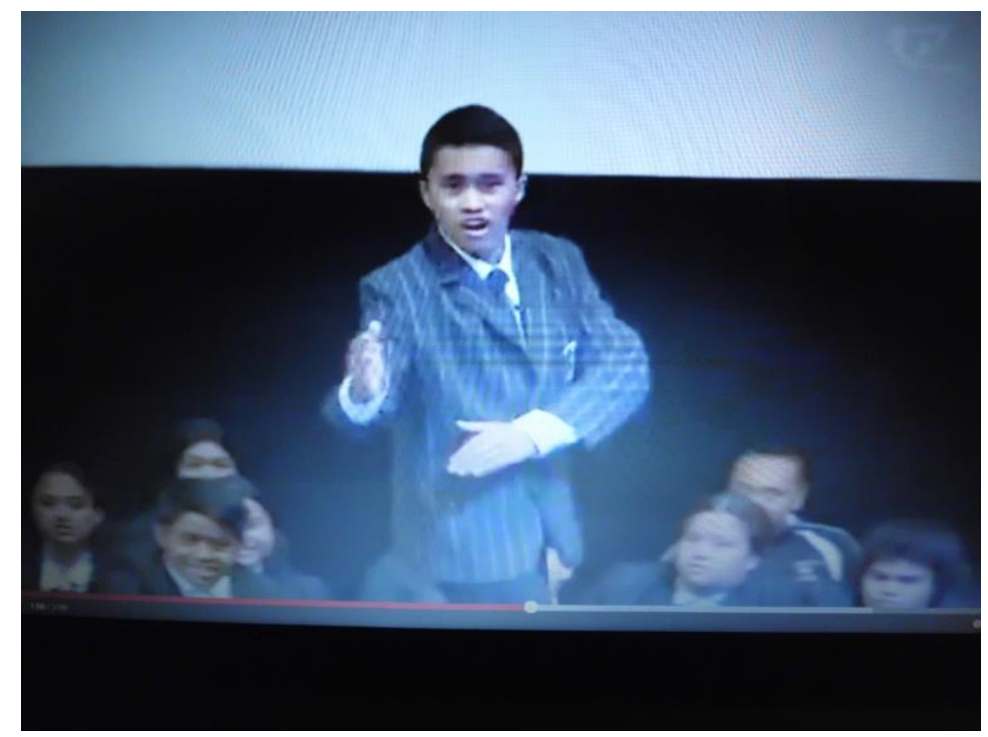

The author's son, Rewi Maniapoto Amoamo, aged 16 years old. Representing a Maori immersion school at the Auckland regional Manu Korero speech competition, he won third place in the senior Te Reo Maori section. 80 Auckland high schools competed.

My son had completed year 9 at Otahuhu College getting the music prize and proficient all round grades before transferring to Maori immersion education for year 10 and 
two-thirds of year 11. At Otahuhu College, Rewi got along with teachers and students showing he was capable, fairminded, and comfortable being Maori and Tongan woven into one person, as opposed to choosing one ethnicity and culture above the other. Looking back, he noted on a personal level the pressure of Maori immersion education was having to be publicly Maori first, and Tongan in private because this identity marker did not belong here.

Rewi did not feel at ease, and it bothered him that his Tongan ancestry and Pacific Islander affiliation did not need to show up in public life. Initially he made an effort to abide with social norms, and represented the Maori immersion school he attended at the Auckland regional Manu Korero speech competition, coming in at third place for the senior Te Reo Maori section. Momentarily on stage he forgot his speech. To smooth over the glitch he performed an impromptu song, dancing light-heartedly like a Pacific Islander by swinging his hips. Television New Zealand's Maori news show Te Karere reported on the event, inserting a snippet of Rewi's song and dance act in their evening news (Harrison, 2014). In many ways, seeing himself on a television sound-bite reaffirmed for Rewi that the Tongan part did not make him defective or deficient. It had given him good things; zany humour and a raucous laugh, easy-going character, the knack of being friendly to people, and a desire to travel the Asia and Pacific regions experiencing countries, cultures, and cuisines.

As a child, Rewi began school at six years old in New Zealand. Six is the legal age of which parents are required to have their child enrolled at primary school, although the majority of New Zealand children start school at five. He was not interested in getting tied down to school routines. It sounded boring and might have cramped his lifestyle. Rewi was busy travelling back and forth to Tonga, staying with my paternal grandmother, my son's great grandma, out in the 
village. He had social freedom in the village. Grandma's nickname was the mayor, second in line to the noble and estate-holder Lord Nuku so the people jested. Everyone knew Rewi was my grandmother's makapuna (great grandchild), which allowed him to do as he pleased without elders and authority figures growling at him.

Grandma Siu's village Kolonga, where my father was born and raised, is a rural farming settlement of just over a thousand people, mainly children and the elderly. Most able bodied adults of my generation have relocated to New Zealand, Australia, and America, employed intermittently as transient workers and remitting money and goods back to their kinfolk at home. Many of the homes are left with no one living in them. Some Kolonga families leave permanently if they are able to by an official immigration route, while others take their chances at overstaying, hoping to remain overseas for good.

My paternal grandmother died when Rewi was nine years old. By this time, I had him in a Maori immersion primary school. He picked up Te Reo Maori fast, and I anticipated that with Grandma Siu's passing he would gravitate towards Maori ethnic and cultural identity seeing he would be fluent in Maori language and we lived in New Zealand. But I was wrong. I had underestimated my son's loyalty.

My belief that the indigenous language one learns to speak as a child establishes the basis of identity and belonging did not straightforwardly fit Rewi. He was just as much Tongan, and believed that in his heart. He would not make that part of him subordinate, even when pressured to. Rewi would transition through boyhood, adolescence, adulthood, and old age carrying direct memory of a Tongan great-grandmother who lived in his ancestral village; Grandma Siu who could not speak English and walked around in bare feet; his old Tongan kui who cared for him before he went to school in New Zealand. 


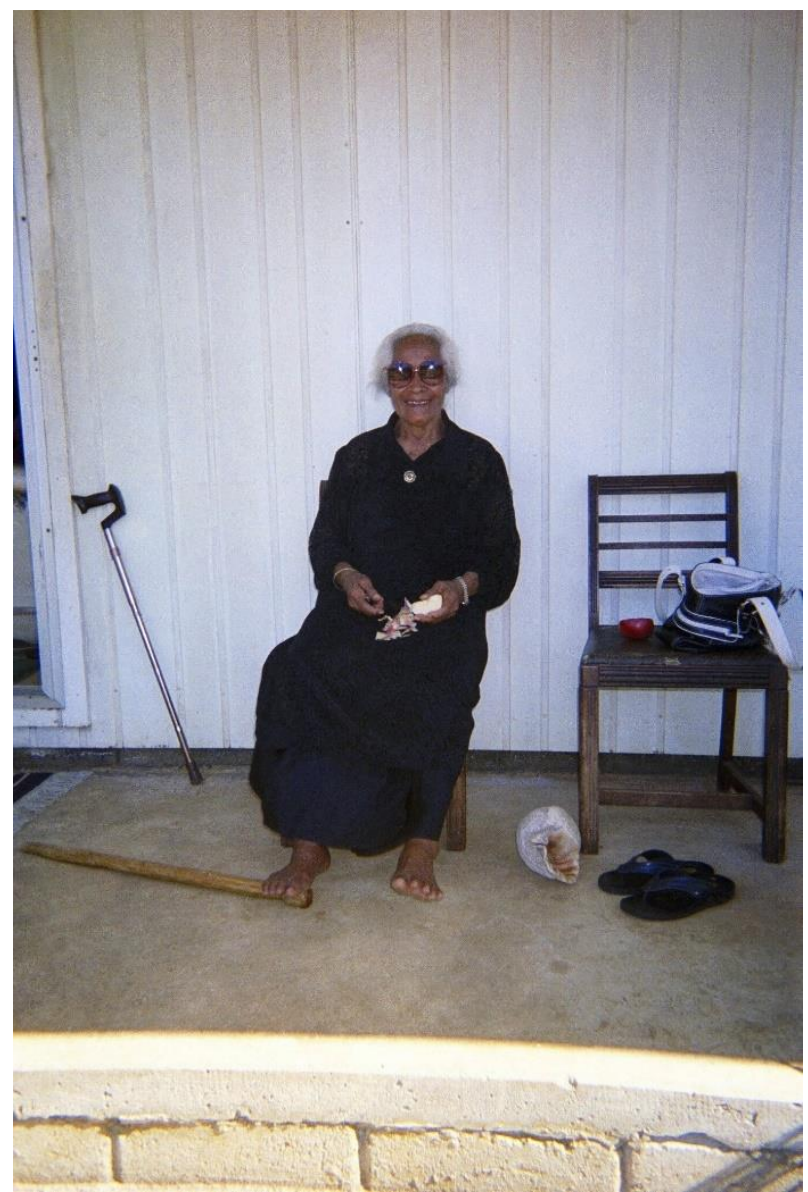

The author's paternal grandmother, Siu Ki Halakakala Tae Mailau, on the veranda of her home in Kolonga, Tonga. The photograph was taken in 2006, two years before her death in 2008.

The morning I took Rewi into Otahuhu College to re-enrol him in year 11 we waited in the foyer to meet with the deputy principal. He was anxious but lit up when three Pacific Islander boys, one Tongan, one Samoan, and one Cook 
Islander, came to greet and hug him before their class. They were his old class mates from year 9. They had not forgotten Rewi by any means, and chatted excitedly about him coming back to their school.

Caught in an ephemeral moment of watching my son, I got what he explained to me about being Maori and Tongan. He said he felt more comfortable going to school with Tongans and Pacific Islanders. I asked him why when he spoke fluent Maori language and we lived in New Zealand. His sense making of a complex identity was traced to childhood memory and emotional attachment: "Mum, it doesn't matter if I don't speak fluent Tongan like granddad. I lived in Tonga with granddad's mum, Grandma Siu, when I was a little boy. I feel comfortable there. Tongans accept me. Tongan kids my age, they're always proud when I say I'm Maori and Tongan. They want me to be part of them."

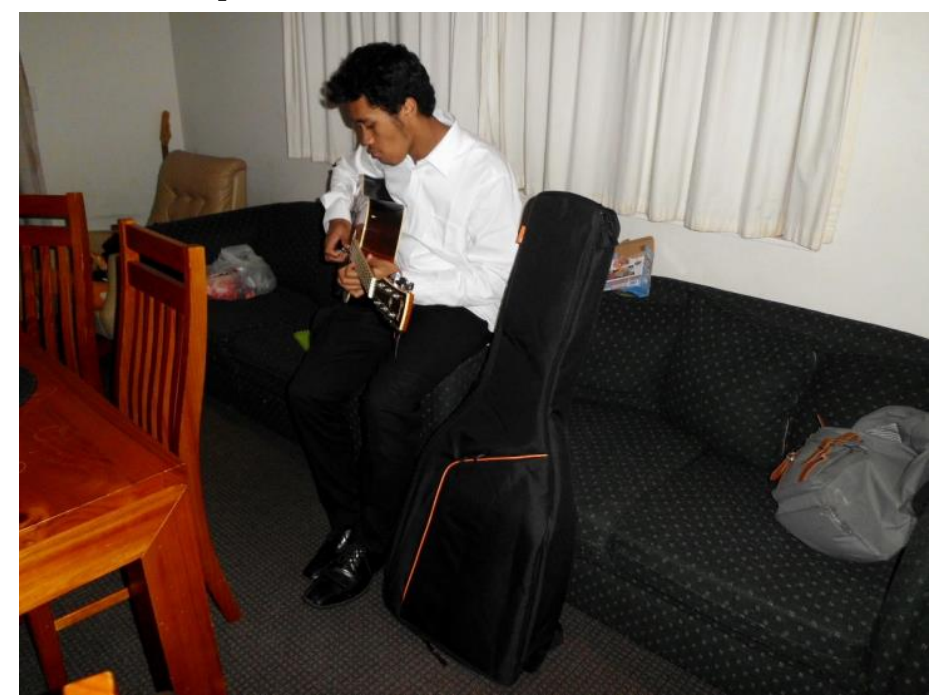

The author's son, Rewi Maniapoto Amoamo, aged 16 years old. Practising for a year 11 music assessment on his 


\section{Ibanez acoustic guitar, a session guitarist is a career possibility.}

Switching to a mainstream public high school has had advantages for Rewi's learning interests in music and performing arts. At first, he judged science, math, and technology to be the pathway for high achievement in senior high school. His logic was the job market dictated subject choice, and to be guaranteed stable employment in today's fast changing world meant studying numeracy based fields. The arts and languages, Rewi chided, were a waste of time, leading to joblessness or lowly paid, unsteady employment. He shunned the thought of a wobbly working life as a starving musician or broke writer, and spurned that even a humanities degree in Asian and Pacific languages did not automatically mean multilingualism guaranteed a job.

Shifting Rewi's mindset away from speculating that the arts and languages were no-brainer subjects for making a respectable living was self-realisation. Determined to attain credits from successfully completing internal assessment pieces in a short period of time before semester four, the final term of the school year when state exams arrived, he found a fit. He achieved his best work in music and languages, the disciplinary cluster he had surmised would take him nowhere in life. He took music seriously as an academic subject, enjoying the fact the year 11 class was small in number, which allowed him to have one-on-one learning time with the teacher.

Rewi spent long-hours practising two acoustic guitar pieces he performed "as a featured soloist" for internal assessment (Otahuhu College, 2014). He laboured to "compose two original pieces of music" as well as "performing a piece of music as a member of a group" (Otahuhu College, 2014). Investing more time and effort in studying music than 
he did for English, a compulsory subject, Rewi looked closely at pursuing music, performing arts, and languages at postsecondary level. If he was serious and passionate about this field as his career, he would find work in the creative industry as a session guitarist were his thoughts.

His music teacher, $\mathrm{Mr} \mathrm{T}$. as the students cordially called him, commended Rewi after his recital "as a featured soloist," saying that he can feel the music and his guitar playing was beautiful (Otahuhu College, 2014). Those were the encouraging words he needed to hear to retune his thinking towards optimism and confidence that out in the big wide world highly-trained and professional musicians and performing artists had immeasurable value, and were treasured.

\section{The more of them, the worse they get}

There is something complexly tangled about the emotional attachment of people to their place of belonging, especially when the place is coloured by state policy, academia, and media as symbolising race, culture, and deficiency. In Rewi's case, he doubted studying the arts and languages could give him job security in the real world after high school where developed countries like New Zealand, not singly poor Pacific Island states such as Tonga, all suffered from contracting economies and limited employment opportunities, even for university graduates. What use was a university degree if it did not warranty in adulthood a stable job and reasonable income he could live on? The truth is my son was mimicking popular statements driven by a certain ideology of the neoliberal kind that he had been exposed to from adult discussion.

Everywhere he turned standard truths were manufactured about what was valuable, post-secondary wise in respect to 
making an income, and what was not. There was Rewi's Tongan grandfather who migrated to New Zealand to take up a trade at Otago Polytechnic in the 1960s and never looked back, so he reminisced. Teachers of math, science, and technology spoke with conviction that the world was geared towards numeracy based employment. Then the New Zealand government fed its message to the masses through media. The government sermon stressed recruiting Pacific Islander students, males in particular, to trade training courses. Added to this formula for life success was getting more of them into science, engineering, technology, and medicine, the university degrees they did not figure highly in (Auckland University of Technology, 2014).

What Rewi absorbed from adult impressions was compounded by the fact Pacific Islanders and South Auckland are conflated to be one and the same, an inseparable amalgamation of people and place where the place is personified to be Pacific. The South is by no means solely or predominantly Pacific. To the contrary, Manukau City has a majority Pakeha population, an accurate reflection of New Zealand's dominant demographic and culture. However, the ethnoscape is to a greater extent than the other three cities encompassing the Auckland region racially and culturally diverse (Appadurai, 1996). The misperception is set off by a convoluted logic in New Zealand where race, culture, and deficiency are distinct concepts blended and mixed up when accounting for, and making sense of, Pacific Islanders and South Auckland.

Deficiency is the overriding dimension in a New Zealand racial hierarchy where Pakeha constitute the norm, the benchmark, the yardstick by which all other races are cultures are measured against. Conventionally, the racial and cultural categorisation of Pacific peoples, Pasifika, and Pacific Islanders, falls short of the Pakeha national average, the 
normal level of achievement in every measurable facet of the human life cycle.

But as Tongan and Pakeha sociologist Karlo Mila mentioned, the criticism from many Pacific Islander leaders of the New Zealand born generation is to "stop mining our kids for deficit" (Mila-Schaaf, 2012). By this, the bordering of children and young people in a deficit model quantifying their racial and cultural incompetence at achieving the Pakeha national average in their everyday lives sets them up to fail at aspiring to be something they are not - Pakeha New Zealanders - the dominant population, class, and culture.

If Pacific Islanders are not the dominant portrayal of New Zealand, then how are they depicted as peoples of multiple ethnicities, cultures, languages, and nationalities, who for convenience are made into a critical mass of sameness? On an overarching level, prevailing research is quick to point out that the New Zealand Pacific population is different. The inference is they are different to Pakeha New Zealanders who signify the cultural norm and national average of achievement in education, employment, income, health and wellbeing.

Put simply, the difference is deficit and the judgement inflicted on the entire Pacific population of South Auckland is that when there are more of them, the worse they get. This rationale is recycled and regurgitated by structures and processes of institutionalised racism where "the racism of low expectations" is the most debilitating force to impede educational achievement (Landsman, 2004). "The soft bigotry of low expectations" is replicated and repeated across the public education system through the prejudicial belief that students of a Pacific background naturally exist below the Pakeha national average, are vulnerable to failure, and require learning intervention, behaviour correction, and cultural modification to achieve something (The Patriot Post, 2014; Anyon, 1995; Reyes and Halcon, 1988; Rothman, 2002). 
Although they might get somewhere with added layers of institutional support, specifically for literacy because it is unquestioningly taken as fact that Pacific Islanders have difficulty reading and writing in formal English, "tucked back in a teacher's subconscious [is the belief] that they are innately less intelligent than their white peers" (Landsman, 2004, p. 28). The widespread estimation is that their written composition and analytical thinking skills are certainly of an inferior standard which is why, unsurprisingly, Pacific students in high school and post-secondary education gravitate to performing arts subjects as in dance, music, and drama. Of course, the mind association is that the arts are lesser, below standard, and inferior to math, science, and technology, and not at all counted as a disciplinary area of academic standing and intellectual merit.

Twelve years ago I published an essay venting my indignant rage at the way South Auckland as a place, and Pacific Islanders living in the South as a people, were mounted in media portraits and hung up in academic research as broken (Brown Pulu, 2002). In desperate need of fixing, repairing, and putting back together again like Humpty Dumpty who had a great fall and never recovered from permanent injury, I was disillusioned with the actuality that deficit theorising was the only lens through which South Auckland and its Pacific population were seen and read.

South Auckland is the imagined terrain of brownskinned urban-ness and migrant Maori and Pacific Island communities in crisis. It is visualised as the Nation's poor house: cheap homes, State housing on market rents, flea markets and backyard sales, island produce and cheap meat off-cuts, white tank-loaves, pani popo and pani maa from largely Asian owned 
bakeries, and brown-skinned bodies. (Brown Pulu, 2002, p. 14).

Garnering the research published today by Pacific Islanders speaking about and for their places and peoples to whom they affiliate, and in many ways represent in academia, I am dismayed and grateful. I say dismayed because the social imaginary created about Pacific Islanders in New Zealand cultivates a research culture of theorising poverty, inequality, hardship, deprivation, and down-and-out depressing living circumstances. In the same breath, I say grateful because I do not research the New Zealand Pacific population, expressly in South Auckland, having made a purposeful decision to specialise in Pacific Island states.

My field of anthropological expertise is Tonga and Pacific Islands' development and regionalism. I have not angled my research career on the New Zealand context and history of Pacific peoples, and like my son Rewi, feel sceptical and suspicious of institutional power coercing and pressuring me to do and be something I am not; that is, be a Tongan New Zealander who researches and writes about Pacific communities of South Auckland. This is not who I am, and definitely not who I aspire to be in my working life.

I feel that strongly about affirming my research expertise in Tonga and the independent Pacific Island states of the South Pacific sub-region (as opposed to the North Pacific, an American sphere of military and geopolitical influence) I would, given an opening came up, migrate to teach for a university in a Pacific Island state, or take up a research and policy position at a regional organisation based in the South Pacific. Defensibly, shifting from the Pacific Rim to the Pacific Islands to live is an overt and obvious strategy demonstrating an individual's work is located in small island developing states. 
On noting that, however, as a South Auckland resident of Tongan ancestry I do have a lay-interest in acquainting myself with research about the New Zealand Pacific population, and emerging hypotheses on what distinguishes the South and its peoples as different. A decade on from my paper, Turangawaewae/Tu'unga'ava'e: Echoes of a place to stand and belong, academic writing still captures the South as "the Nation's poor house" (Brown Pulu, 2002, p. 14).

Its distinctiveness persists in language depicting "communities in crisis," and if anything, research on Pacific Islanders in places like South Auckland, an area of New Zealand where communities are large in number and visible to the public, is stuck on imagery of despairing poverty (Brown Pulu, 2002, p. 14). Karlo Mila's imaginative account evokes and echoes the hopelessness of living in deprivation.

It is what happens when the real banks won't lend you money and loan sharks are wooing you, cheap bait for bad debt. And when no one you know actually owns their own house, or knows what a PhD is, or has plans for their future, and most of your time is spent making sure you can put food on the table and the power won't get cut off. And you know there is no money for extras like Saturday sports for your talented children because you can't afford boots, or fees, or Lucky Book Club books, and your children already know that there are things in life that are beyond their reach, that are not for them, and they are already feeling it in ways that make them burn inside. (Mila, 2013).

The excerpt from Karlo Mila's book chapter called Only One Deck was published in a collection of essays edited by journalist Max Rashbrooke on Inequality: A New Zealand Crisis 
(Mila, 2013; Rashbrooke, 2013). Her chapter spoke expressively to Pacific inequality. I am not saying that poverty does not exist in South Auckland, or that class and social inequalities between races and cultures of New Zealand are not on the rise. What I am saying is that as a research paradigm "it is what happens when the real" people who are Pacific Islanders living on landscapes painted in poverty, such as South Auckland, are counted out of the author's story (Mila, 2013).

Who is telling this tale? Is it the storyteller and script writer, or the figures written about, spoken of, and staged in a scenario? Consequently, when the human subject put under the microscope is gagged and smothered from speaking for themselves, who holds the power to define what we know about them - the narrator or the audience? (Lincoln, 1997).

In critically re-reading the text and context of Mila's 2013 book chapter, I admit to showing my personal and professional subjectivity on two counts. On a personal level as a Tongan mother of mixed ethnicity living in South Auckland and witnessing my children grow to adulthood in this place, it irks to see a Pacific poverty narrative written over and about me and my kind by a Tongan and Pakeha researcher not from, and not residing in, the South.

As an anthropologist who situates my writing in ethnographic fieldwork where I am part and parcel of the field, the subject, the place and people I am asking questions about and studying, the narrator's description of what Pacific poverty in New Zealand means does not quite ring true. The author stands outside of first-hand experience of the subject, but insists on speaking of Pacific poverty as a known experience. It is other people's knowing she attempts to seize, without validation from the subject that her storytelling relates to their lived experience (Fernandez, 2006). 
How do these children present themselves creditably to our society without the shame and stigma of identifiable poverty further compounded by ethnically marked bodies? How do they ward off the pain of shame and humiliation? How do they grow up feeling good about themselves and society, and hopeful for their future? (Mila, 2013).

Here, I have again inverted and reworded an excerpt from Mila's book chapter to return the Western gaze at inequality faced by an impoverished Pacific in New Zealand; a Western gaze adopted by many researchers of Pacific affiliation to survey the people they claim to speak for (Lehti et al, 2010). A question relating to trustworthy and true research is "how do these [New Zealand born researchers of Pacific Islander ancestry] present themselves creditably to our society without the shame and stigma of identifiable" inauthenticity? (Mila, 2013; Johnson, 2003).

The politics of authenticity in which policing who is a spurious parody of an original form, a fake copy of the real McCoy that is, confounds the structures and strictures separating economy and culture, as Judith Butler argued in her essay, Merely Cultural (Butler, 1997, 1998). On the one hand, social scientists have considered that "class and race struggles are understood as pervasively economic" by nature (Butler, 1998, p. 38). In this sense, capitalism is the global system of economy which reproduces wealth disparity. This is illustrated by disproportionately high numbers of the poor and underclass being peoples of race, colour, and non-Western culture.

Conversely, Butler put forward an important critique in Merely Cultural by referring to Guyanese and English professor of American and English literature Paul Gilroy, along with Jamaican born professor of cultural studies and sociology 
Stuart Hall (Butler, 1998, p. 38; Gilroy, 1992). The skill to competently examining class and race is understanding they do not operate independently, and therefore, have to be analysed in direct relationship to each other as a mutually associated system of power.

Sometimes this takes the form of trying to resubordinate race to class, failing to consider what Paul Gilroy and Stuart Hall have argued, that race may be one modality in which class is lived. In this way, race and class are rendered distinct analytically only to realize that the analysis of one cannot proceed without the analysis of the other. (Butler, 1998, p. 38).

Problematically Mila's book chapter did not perform the task of scrutinising class and race interdependency. Hers was an old-fashioned sociological story about poverty as a product of unfettered capitalism of the neo-liberal variety, a system of economy designed to keep a small percentage of the population at the financial top-end by subjugating the poor at the rear-end. Her reasoning that Pacific Islander child poverty was perceptible to outsiders by seeing their "ethnically marked bodies" was not interrogated as racialization, a method by which the conflation of class and race forges a single identity (Mila, 2013).

Concisely, this is where research fashioned by New Zealand Pacific Islanders, whether they are migrants or born here, comes unstuck and suffers a systematic breakdown. Using an outdated research tradition of conventional sociology to interpret complex circumstances shaping Pacific Islanders' lives "[fails] to connect with [their] experiences," to rephrase Paul Gilroy's introduction from his book, There Ain't No Black in the Union Jack (Gilroy, 1992, p. xiii). 
It is no longer possible to ignore the way that insights derived from those traditions sometimes fail to connect with the experiences or understanding of younger people or with the vision of African and Asian settlers whose colonial and post-colonial sufferings have been necessarily different. (Gilroy, 1992, p. xiii).

Gilroy was gesturing to the generational shift that had taken place between African and Asian migrants born in homeland states before political independence when they were still European colonies, and their children and grandchildren born and raised in the United Kingdom. This is the social phenomenon migrant and New Zealand born researchers of Pacific ethnicities and cultures grapple to explain by sophisticated theory that is reasoned out convincingly.

Bluntly speaking, there exists no one-size-fits-all resolution to intergeneration change and social fracture in Pacific communities of New Zealand, Australia, and America (Clifford, 1994; Spickard et al, 2002). Likewise, academics should not be fixated on solving the conditions of social transformation by inventing diasporic generations as cultural identity research problems, when clearly, they are agents of change (Brown Pulu, 2013a, 2013b; Hall, 1990, 1996, 1997; Franklin, 2003). Tracing back to the politics of authenticity and policing who is real compared to fake (which I mentioned earlier in this piece), this is the longstanding intersection where research and publications by Pacific Islanders crosses over, collides, contests each other's credibility, and sometimes colludes. Why is this?

To respond, the New Zealand state continues to mould classes and cultures of people. A system of racial classification derived from the country's British colonial settler roots is the out-of-date model. Pakeha New Zealanders symbolise the national average and social norm. Maori, in 
many ways, is the identity marker constructed as the Native opposite of Pakeha. While Pacific peoples, Pasifika, Pacific Islanders are all signposts that inadequately speak for the diverse peoples the labelling is meant to sweep together and contain.

The obvious fact is this is a divide-and-rule structure propagating social stratification. For Pacific Islanders, the measurement of success is how fast an individual becomes more like the centre of power, and less like the margins where their kind is fixed, flawed, and failing the system. Thus, a false expectation surfaces that this identity mass would mechanically unify and orchestrate some kind of ethnic mobilisation movement (Olzak, 1983; Nagel and Olzak, 1982). Undoubtedly then, the politics and poetics of culture and difference is central to understanding the various kinds of reasoning Pacific academics in the university system use to validate why cultural identity is an esteemed resource for education advancement (Rattansi, 1992).

The following section concludes this essay by analysing the strategic shift from Pasifika to the Pacific Islands region that the office of Pacific advancement at Auckland University of Technology has engineered. How does moving research narratives beyond the diaspora borderlands towards social inclusion in oceanic dialogues and interchanges enrich initiatives on the Auckland University of Technology South campus? (Hau'ofa, 1994, 2008; Diaz and Kauanui, 2001; Lilomaiava-Doktor, 2009a, 2009b; Taumoefolau, 2011).

\section{Kinds of cultural reasoning}

On October 14th 2014, Walter Fraser, head of Pacific advancement at Auckland University of Technology, wrote a two-page letter to selected members of academic staff and wider university stakeholders in New Zealand and Pacific 
Island states (Fraser, 2014). Accompanying the letter was a copy of Spasifik Magazine showcasing staff research projects on Pacific demography and health. Speaking with him at our workplace, I was personally quite chuffed when he mentioned one recipient was my matrilineal uncle, the Prime Minister of Tonga Lord Tu'ivakano. Fraser had been on the job for six months, circulating a university update of Pacific activities through his regional networks. Prior to his appointment he was the director of the centre for Pacific studies at the University of Auckland; the rival university on the opposite side of the street from Auckland University of Technology.

The fact the two universities sat shoulder to shoulder in the centre of Auckland city, and both of them had Auckland in their names, confused Pacific Island governments. Many ministers and senior bureaucrats did not click they were different institutions, mixing them up as the same place. This indicated a change in regional politics and priorities. No longer was New Zealand the core country where Pacific Islanders got university qualifications. There were more education options on offer these days, and with Pacific Island states pivoting to China and Asia, state bureaucrats and scholarship recipients were getting degrees and training at universities and technical institutes in Beijing, Tokyo, Singapore, Bangkok, and even Vladivostok, to name a few places.

Fraser was Auckland University of Technology's third appointment to heading Pacific advancement after Michael Jones and Pauline Winter, and his first newsletter informing staff and stakeholders of what his office had achieved in a short period showed he had an edge (Teaiwa, 2001). A graduate of the University of the South Pacific in Fiji who was the registrar for eight years, it was Fraser's connections to Fiji and South Pacific states, in particular to the institutional and political hierarchy, which set him apart from his predecessors. 
His conceptualising of the Pacific was not New Zealand located and dislocated. He had not been solely disciplined by a New Zealand university education to view ocean states as New Zealand and Australia's colonies, business and trade backyard, next door neighbours when it suited, and extension of power and authority. Geopolitically, the Pacific region of the 21 st century was busy remodelling itself under a new polity designed and led by Pacific Island states (Morauta, 2013; Pacific Plan Review, 2013; Naidu, 2013). At the helm of change was Fiji's attempt to create a new centre of power to counter the traditional Pacific Islands Forum by establishing the 2013 Pacific Islands Development Forum, which excluded New Zealand and Australia's membership (Dornan, 2013; Pacific Islands Development Forum, 2014).

One thing was for sure, the 21 st century was different from the past. This century signified a Pacific Islands region where political leaders had partly (not fully) picked up and run with aspects of Epeli Hau'ofa's call for an interconnected Oceania. Some political leaders were manoeuvring Hau'ofa's idea that Our Sea of Islands should make a case for the regional common good, rather than hashing out longstanding divisions prohibiting individual states from cooperating in mutual teamwork (Hau'ofa, 2008).

Openly I admit my preferences for Fraser's leadership on the Pacific front at Auckland University of Technology. His leaning towards an Epeli Hau'ofa school of thought, (which emerged as a discourse produced at the University of the South Pacific in Fiji where Hau'ofa taught on academic staff), partially links to the theoretical lens through which I read and interpret Oceania histories, literatures, politics, the arts, and indigenous ways of knowing how social organisation operates in the Pacific Islands (Brown Pulu, 2014a, 2014b; Hau'ofa, 1994, 2008). 
Exemplifying this point, Fraser's concluding remarks in his letter purposely reframed the Pacific at Auckland University of Technology to shift beyond the New Zealand border into "wider regional interests and ambitions" (Fraser, 2014).

Finally, on a relatively small but important matter, you may have noticed that the name OPA [Office of Pasifika Advancement] has changed. Following my request, the Vice Chancellor and EMT [Executive Management Teaml have approved the change to "Office of Pacific Advancement" and the new title for my role is "Head of Pacific Advancement." While we remain committed to the advancement of our domestic "Pasifika" communities, the new title more accurately reflects our wider regional interests and ambitions. (Fraser, 2014).

Fraser's switchover from using the name Pasifika to now being called the office of Pacific advancement exercised a quiet revolution of rethinking how the university envisaged itself in, not close by or perched on the rim of, the Pacific Islands region (Darling-Hammond, 1996). To be in the Pacific Islands region as a New Zealand university was a dangerous and unstable position to take on. For one, it potentially wedged open the Pacific to be inclusive of Maori, the indigenous peoples of New Zealand. In New Zealand, Maori were Native to the land and separate from Pacific Islanders who were migrants, or the descendants of migrants, from the ocean states.

But if the university was in the ocean as an ocean state institution, then Maori could be counted in as Polynesians and indigenous peoples of the Pacific too. New Zealand Pacific Islanders would object, without a doubt, to including Maori in the Pacific. It inflamed an irrational fear that it afforded Maori 
excessive identity space and power with the likelihood they would compete with the Pacific for limited resources, and consequently, take away educational, research, and employment prospects that should go to the real Pacific Islanders first and foremost.

Fraser was trying something innovatory. He was breaking with the New Zealand Pacific tradition of exclusionary politics. Setting apart Pacific from Maori and setting them against each other, detaching Pasifika identity from Pacific Island states, and differentiating between migrants and the New Zealand born Pacific population, typified the Pacific tradition in New Zealand.

Really it was about policing identity borders and authorising who fitted in the New Zealand construct of being counted as Pacific, Pasifika, Pacific Islander, and who was out, outside the limits, or from overseas as in belonging to a different country such as Fiji, Samoa, or Tonga. New Zealanders of Pacific ancestry did not practice inclusiveness with maturity and refinement because historically, the New Zealand state did not rank racial inclusion highly.

Two interrelated initiatives "on the cards over the coming months" which Fraser briefly outlined gave context and content to reframing the Pacific. First, a "preparatory programme" would be trialled in summer school on the South campus (Fraser, 2014). Recruiting "school-leavers from lowdecile schools in the Manukau region," the foundation course was designed with "Pacific communities" in mind (Fraser, 2014).

The following developments are also on the cards over the coming months:

A pilot summer university preparatory programme based on our South Campus focussing on schoolleavers from low-decile schools in the Manukau region. 
It is expected that the majority of participants will be from our Pacific communities. Over the last few weeks, I have been visiting key schools in this region to meet with principals, deans and career advisors to discuss the initiative and their responses have been overwhelmingly positive and supportive; (Fraser, 2014).

Second, a "lecture series titled Oceanian Perspectives" was set for the 2015 academic year. It could be said the series resembled a tribute to Epeli Hau'ofa's theory of oceanic identity taken from his essay, The Ocean in Us (Hau'ofa, 2000). Published in Anthony Hooper's book on Culture and Sustainable Development in the Pacific, Hau'ofa wrote a proenvironmentalist and conservationist chapter in relation to the Pacific Ocean and its peoples (Hooper, 2000). His argument etched out a dual edge in two excerpts I have cited here. "The formation of an oceanic identity is really an aspect of our waking up to things that are already happening around us," and, "no people on earth are more suitable to be the custodians of the oceans than those for whom the sea is home" (Hau'ofa, 2008, p. 55, 57).

I noted before that political leaders had partly (not fully) picked up and run with aspects of Epeli Hau'ofa's call for an interconnected Oceania. By this, The Ocean in Us contained fundamental ideas that have been cut and pasted to official speeches delivered by heads of state and government, as well as cabinet ministers from across the Pacific Islands region (Hau'ofa, 2000). Rewording Hau'ofa, "waking up" to the reality that climate change and environmental ruin were upon us presented one pervasive factor affecting an oceanic identity (Hau'ofa, 2008, p. 55).

Concomitantly, the belief that oceanic peoples were, and still are, the rightful "custodians of the oceans" was the second motivational factor (Hau'ofa, 2008, p. 57). Managing and 
protecting the ocean and its natural resources had propelled political leaders to take action on the regional stage, as was the case when Palau President Tommy Remengesau lobbied the sixteen member states to the Pacific Islands Forum to assent to The Palau Declaration on the Ocean: Life and Future at the 45th meeting in Koror, Palau, from July 29th to August 1st 2014 (Hau'ofa, 2008, p. 57; Pacific Islands Forum Secretariat, 2014a, 2014b).

Fraser's take on Hau'ofa's The Ocean in Us had a particular angle he was plugging (Hau'ofa, 2000). His focus was on reshaping a regional identity that sees "Oceania as comprising of human beings with a common heritage and commitment, rather than as members of diverse nationalities and races" (Hau'ofa, 2000, p. 36). This was the Hau'ofa brand of oceanic humanism in which the individual and collective agency of human beings was believed to be a force for effecting social change.

A high profile, public seminar/symposia/lecture series titled Oceanian Perspectives will be launched in 2015. In his landmark essay "The Ocean in Us," renowned academic and philosopher, Professor Epeli Hau'ofa said: "A Pacific regional identity means a Pacific Islander identity. But what or who is a Pacific Islander? The issue should not arise if we consider Oceania as comprising human beings with a common heritage and commitment, rather than as members of diverse nationalities and races. Oceania refers to a world of people connected to each other. The term Pacific Islands Region refers to an official world of states and nationalities. John and Mary cannot just be Pacific Islanders; they must first be Ni Vanuatu, or Tuvaluan, or Samoan. For my part, anyone who has lived in our region and is committed to Oceania, is an 
Oceanian. This view opens up the possibility of expanding Oceania progressively to cover large areas and more peoples than is possible under the term Pacific Islands Region." (p. 36). Calling the series "Oceanian Perspectives" would offer us an opportunity to provide a more inclusive platform to discuss the range of important issues facing Oceania. (Fraser, 2014).

To offer a brief comparison of the two events or "developments" as Fraser detailed in his letter, an overarching rationale links them (Fraser, 2014). The foundation course for Pacific "school-leavers from low-decile schools" on the South campus prioritised gaining literacy and numeracy credits, which is the essential component of the New Zealand government qualifications standards system called the National Certificate of Education Achievement (Fraser, 2014; New Zealand Qualification Authority, 2014). Historically, the University of Auckland had provided bridging avenues to assist young Pacific peoples to gain entry into university degree programmes. Therefore, why would a "preparatory programme" not work effectually with South Auckland Pacific Islanders? (Fraser, 2014).

By contrast, the "lecture series titled Oceanian Perspectives" was unquestionably fixed on the work of Epeli Hau'ofa in redefining the Pacific Islands region as "an oceanic identity" (Hau'ofa, 2008, p. 55). Amplifying Oceania "to cover large areas and more peoples than is possible under the term Pacific Islands Region" tied into Hau'ofa's notion that the Pacific diaspora in New Zealand, Australia, and America is an expansion of the Pacific Island homelands (Hau'ofa, 2000, p. 36; Hau'ofa, 2008). Fraser's emphasis on building an "inclusive platform to discuss the range of important issues facing Oceania" was purposeful (Fraser, 2014). Aiming to 
incorporate the New Zealand Pacific diaspora in oceanic dialogues, here was a strategy that might potentially reposition Maori in the Pacific, in an oceanic identity. Rather than sitting on the fringe of a changing regional polity where Pacific Island states put themselves at the centre not the margin, why could the New Zealand Pacific, and to a certain extent Maori, not be included in a new identity arrangement?

I do see the logic in offering a South campus foundation programme for "school-leavers from low-decile schools in the Manukau region" (Fraser, 2014). Equally, I endorse performing arts curricula inclusive of Pacific creative communities being developed and delivered. That is, given the context, content, and provision of undergraduate papers are relevant and credible to the communities the university recruits and equips with a degree qualification. On the flip side, when it boils down to politicking around cultural identity, I am sceptical that an oceanic nametag (just like wearing the Pacific, Pasifika, Pacific Islander badge) is going to destabilise and knock off balance conventional definitions of race, ethnicity, language, country, nationality, and citizenship that people ordinarily lay claim to.

On a final note, for this essay I have elected to privilege the identity stamp Pacific Islander over Pacific peoples and Pasifika. To me, this was the least affronting but broadest categorisation of the three. Given the choice I would have none of it for myself, of which I write in disagreement with Epeli Hau'ofa's endeavour to get people migrating from Pacific Islander to oceanic as a distinguisher of living, or having lived in Oceania - Our Sea of Islands as he put it (Hau'ofa, 2008).

I am Tongan. I have mixed ancestry. My Native tongue is English. I was born in New Zealand. My loyalty and research is dedicated to the Kingdom of Tonga as a country, not to an oceanic identity borrowed by every human being who sees they share an affinity with saltwater storytellers. Oceanic identity 
is ideologically imbued talk. All identity constructs, however arranged, are highly politicised to serve a social purpose, stake out territory, and claim belonging to place and people. I do not want to be labelled Pacific, Pasifika, Pacific Islander, oceanic. This is my choice to make, my personal sovereignty, my identity turf, and for no outside force to invade and take over. Just saying. 


\section{References}

Anae, M. Et. Al. (2002). Pacific Peoples and Tertiary Education: Issues of Participation. Report Prepared for the Ministry of Education by Auckland Uniservices Limited, a Company of the University of Auckland, February 25, Pp. 1-161.

Anyon, J. (1995). Race, Social Class, and Educational Reform in an Inner-city School. Teachers College Record, 97 (1): 69-95.

Appadurai, A. (1996). Modernity at Large: Cultural Dimensions of Globalization. Minneapolis, United States: University of Minnesota Press.

AUT University. (2014). AUT's South Campus. AUT University: Auckland University of Technology, Auckland, New Zealand, October 25. Retrieved from

http://www.aut.ac.nz/study-at-aut/campuses/south-campus

Brown Pulu, T. J. (2002). Turangawaewae/Tu'ungava'e: Echoes of a place to stand and belong. Journal of Maori and Pacific Development, 3 (2): 14-30.

Brown Pulu, T. (2011). Shoot the Messenger: The report on the Nuku'alofa reconstruction project and why the Government of Tonga dumped it. Nuku'alofa, Kingdom of Tonga: Taimi Publishers.

Brown Pulu, T. (2013a). Chapter 3: Voluntary Work in the Transnational Village. In Mana Ngakau: Community Compassion Maori and Pasifika Volunteer Work, edited by F. Te Momo, L. George, and T. Brown Pulu. Auckland, New Zealand: Directorate of Pasifika, Office of the Assistant Vice Chancellor Maori and Pasifika, Massey University, Albany, Pp. 23-48.

Brown Pulu, T. (2013b). This lazy Native's quitting the daytime job. Going home to the village. Yeah right. In Pacific Identities and Well-Being: Cross-Cultural Perspectives, edited by M. Nelson Agee, T. McIntosh, P. Culbertson, and C. 'O. Makasiale. Dunedin, New Zealand: Otago University Press, Pp. 84-102.

Brown Pulu, T. (2014a). Clash of Civilisations: Tonga and the West. Te Kaharoa: The e-Journal on Indigenous Pacific Issues, 7 (1): 254344.

Brown Pulu, T. (2014b). Minerals and Cucumbers in the Sea: International Relations Will Transform the Tongan State. Te Kaharoa: The e-Journal on Indigenous Pacific Issues, 7 (1): 383474. 
Butler, J. (1997). Merely Cultural. Social Text 52/53, 15 (3/4): 265277.

Butler, J. (1998). Merely Cultural. New Left Review, I (227): 33-44.

Clifford, J. (1994). Diasporas. Cultural Anthropology, 9 (3): 302-338.

Darling-Hammond, L. (1996). The Quiet Revolution: Rethinking Teacher Development. Educational Leadership, 53 (6): 4-10.

Diaz, V. and Kauanui, J. K. (2001). Native Pacific Cultural Studies on the Edge. The Contemporary Pacific, 13 (2): 315-341.

Dornan, M. (2013). Pacific Islands Development Forum Launch in Fiji. Development Policy Centre, Crawford School of Public Policy, College of Asia and the Pacific, Australian National University, Canberra, Australia, August 13. Retrieved from

http://devpolicy.org/in-brief/pacific-islands-development-forumlaunch-in-fiji-20130813/

Fernandez, J. W. (2006). Silences of the Field. In Silence: The Currency of Power, edited by M. L. Achino-Loeb. New York, United States: Berghahn Books, Pp. 158-173.

Franklin, M. (2003). I Define My Own Identity: Pacific Articulations of 'Race' and 'Culture' on the Internet. Ethnicities, 3 (4): 465-490.

Fraser, W. (2014). Letter from Walter Fraser: Head of Pacific Advancement, Auckland University of Technology, Auckland, New Zealand, October 14, Pp. 1-2.

Gilroy, P. (1992). There Ain't No Black in the Union Jack. London, United Kingdom: Routledge.

Hall, S. (1990). Cultural Identity and Diaspora. In Identity, Community, Culture, Difference, edited by J. Rutherford. London, United Kingdom: Lawrence and Wishart, Pp. 222- 237.

Hall, S. (1996). Introduction: Who Needs Identity? In Questions of Cultural Identity, edited by S. Hall and P. du Gay. London, United Kingdom: Sage Publications, Pp. 1-17.

Hall, S. (1997). Chapter 9: The Local and the Global: Globalization and Ethnicity. In Dangerous Liaisons: Gender, Nation, and Postcolonial Perspectives, edited by A. McClintock, A. Mufti, and E. Shohat. Minneapolis, United States: University of Minnesota Press, Pp. 173-187. 
Harrison, R. (2014). Manu Korero fosters competition, strengthens whanaungatanga. Te Karere, Television New Zealand, Auckland, New Zealand, June 13. Retrieved from

https://www.youtube.com/watch?v=f6BDSBSH4CE

Hau'ofa, E. (1994). Tales of the Tikongs. Honolulu, Hawai'i, United States: University of Hawai'i Press.

Hau'ofa, E. (2000). The Ocean in Us. In Culture and Sustainable Development, edited by Anthony Hooper. Canberra, Australia: Australian National University E Press, Pp. 32- 43.

Hau'ofa, E. (2008). We Are The Ocean: Selected Works. Honolulu, Hawai'i, United States: University of Hawai'i Press.

Hooper, A. (Ed.) (2000). Culture and Sustainable Development. Canberra, Australia: Australian National University E Press.

Johnson, E. P. (2003). Appropriating Blackness: Performance and the Politics of Authenticity. Durham, North Carolina, United States: Duke University Press.

Landsman, J. (2004). Confronting the Racism of Low Expectations. Closing Achievement Gaps, 62 (3): 28-32.

Lehti, A. H. (Et. Al.) (2010). "The Western Gaze" - An Analysis of Medical Research Publications Concerning the Expressions of Depression, Focusing on Ethnicity and Gender. Health Care for Women International, 31 (2): 100-112.

Lilomaiava-Doktor, S. (2009a). Beyond "Migration:" Samoan Population Movement (Malaga) and the Geography of Social Space (Va). The Contemporary Pacific, 21 (1): 1-32.

Lilomaiava-Doktor, S. (2009b). Samoan Transnationalism: Cultivating 'Home' and 'Reach.' In Migration and Transnationalism: Pacific Perspectives, edited by H. Lee and S. T. Francis. Canberra, Australia: Australian National University E Press, Pp. 57-71.

Mila, K. (2013). Chapter 6: Only One Deck. In Inequality: A New Zealand Crisis, edited by M. Rashbrooke. Auckland, New Zealand: Bridget Williams Books.

Mila-Schaaf, K. (2012). Theorising advantage in a context of disparity: Exploring determinants of health and wellbeing among the Pacific population growing up in New Zealand, Public Lecture at the University of Otago, Wellington, New Zealand, October 26. Retrieved from

https:/ / www.youtube.com/watch?v=aH3KMwQHwtY 
Morauta, M. (2013). Presentation on the Pacific Plan Review. Pacific Island Forum Leaders' Meeting, Majuro, Marshall Islands, September 4, Pp. 1-10.

Naidu, V. (2013). Commentary on Professor Anthony Beattie's Governance Think Piece for the Pacific Plan Review 2013. School of Government, Development and International Affairs, The University of the South Pacific, Suva, Fiji, May 14, Pp. 1-5.

Nagel, J. and Olzak, S. (1982). Ethnic Mobilization in Old and New States: An Extension of the Competition Model. Social Problems, 30 (2): 127-143.

New Zealand Qualification Authority. (2014). NCEA: National Certificate of Education Achievement. New Zealand Qualification Authority, Wellington, New Zealand, October 30. Retrieved from

http://www.nzqa.govt.nz/qualificationsstandards/qualifications/ncea/

Lincoln, Y. S. (1997). Self, Subject, Audience, Text: Living at the Edge, Writing in the Margins. In Representation and the Text: ReFraming the Narrative Voice, edited by W. G. Tierney and Y. S. Lincoln. Albany, New York, United States: State University of New York Press, Pp. 37-56.

Olzak, S. (1983). Contemporary Ethnic Mobilization. Annual Review of Sociology, 9: 355-374.

Otahuhu College. (2014). Otahuhu College: Summary of Assessments, Rewi Amoamo. Otahuhu College, Auckland, New Zealand, October 21.

Pacific Islands Development Forum. (2014). Pacific Islands Development Forum. Pacific Islands Development Forum Secretariat, Suva, Fiji, October 30. Retrieved from

http://pacificidf.org/overview/

Pacific Islands Forum Secretariat. (2014a). Forty-Fifth Pacific Islands Forum: Koror, Republic of Palau, 29 - 31 July 2014, Forum Communique, Pp. 1-7.

Pacific Islands Forum Secretariat. (2014b). Forty-Fifth Pacific Islands Forum: Koror, Republic of Palau, 29 - 31 July 2014, Annex B, Palau Declaration on the Ocean: Life and Future, Pp. 1-3.

Pacific Plan Review. (2013). Review Note No. 7: Alternative Development Paths. Pacific Plan Review 2013, Pacific Island Forum, Suva, Fiji, July 15, Pp. 1-11. 
Rashbrooke, M. (Ed.) (2013). Inequality: A New Zealand Crisis. Auckland, New Zealand: Bridget Williams Books.

Rattansi, A. (1992). Changing the subject? Racism, culture and education. In Race, Culture and Difference, edited by J. Donald and A. Rattansi. London, United Kingdom: Sage Publications, Pp. $11-48$.

Reyes, M. and Halcon, J. (1988). Racism in Academia: The Old Wolf Revisited. Harvard Educational Review, 58 (3): 299-315.

Rothman, R. (2002). Closing the Achievement Gap: How Schools are Making it Happen. The Journal of the Annenberg Challenge, 5 (1): $1-12$.

Spickard, P. (Et. Al.) (Eds.) (2002). Pacific Diaspora: Island Peoples in the United States and Across the Pacific. Honolulu, Hawai'i, United States: University of Hawai'i Press.

Taumoefolau, M. (2011). Decolonising Pacific Studies: Privileging Pacific Languages and Indigenous Knowledges. In Talanoa Rhythms: Voices from Oceania. Auckland, New Zealand: Masilamea Press, Office of the Pasifika Directorate, Massey University, Albany, Pp. 59-68.

Teaiwa, T. K. (2001). L(0)osing the Edge. The Contemporary Pacific, 13 (2): 343-357.

The Patriot Post. (2014). Right Opinion: Michael Gerson. The Patriot Post, Tennessee, United States, October 25. Retrieved from http://patriotpost.us/columnists/27/bio Constitution 